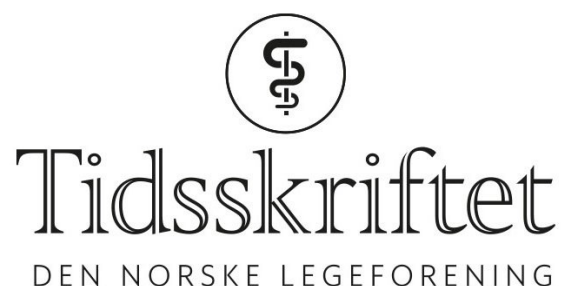

DEN NORSKE LEGEFORENING

\title{
T-E. Widerøe svarer
}

KOMMENTAR

\section{TOR-ERIK WIDERØE}

E-post: tor-erik.wideroe@ntnu.no

Tor-Erik Widerøe er professor emeritus.

Ingen oppgitte interessekonflikter.

Takk for en kort, men utfordrende kommentar til min artikkel. Du stiller spørsmål som jeg ikke kan gi et helhetlig svar på, men jeg kan gi noen generelle betraktninger som kan være opplysende.

Epigenetikken forandrer ikke genene, men er kjemiske endringer som biologisk sett ikke er permanent og derfor kan defineres som reversible. Disse reaksjonene utløses av de omgivelser og opplevelser vi utsettes for. Det gjør at biblioteket av inaktive gener aktiveres og aktive gener inaktiveres. Genuttrykket endres. Nyere forskning viser imidlertid at uten målrettete tiltak kan genuttrykket overføres til neste generasjon og kan være permanente gjennom flere slektsledd $(1,2)$. Prenatalt vil miljøet i mors liv endres ved stress, panikk, angst og mors livsstil. Denne «epigenetiske arven» kan være avgjørende for barnets psykiske helse (1) og intellekt (3) etter fødselen. Psykolog Roar Foss skrev i Tidsskriftet for Norsk Psykologforening «ingen gener for psykiske lidelser» (4). Kanskje er psykisk helse miljøavhengig og epigenetisk. Kvinner er mer påvirket av krigsstress sammenlignet med menn, slik som du viser til. Spesielt etter fødselen kan også den biologiske far påvirke barnet epigenetisk.

Dere sitter inne med opplysninger om psykisk helse på personer som har vært ute i krigsområder. Som du har vist til, er det gjort epigenetisk forskning på veteraner fra Vietnamkrigen og på flere slektsledd etter Holocaust (2).

Epigenetikk er påvirkbar av psykoterapi, men også av et ivaretagende miljø for eksempel lystbetont fysisk aktivitet. Miljøet påvirker mennesker forskjellig, og en nøye vurdering av personlighet og psykisk helse før og etter eksponering er viktig og nødvendig. Her ligger mye av ansvaret.

Avslutningsvis vil jeg nevne asylsøkere. De kan være sterkt preget av krigsopplevelser, stressbelastning under flukt og under integrering i samfunnet. Muligens danner det grunnlag for eventuell kriminalitet, sykdom og tidlig $\mathrm{d} ø$ d. Psykisk syke lever 20 år kortere (5). Det kan bli vårt ansvar gjennom flere generasjoner.

\section{LITTERATUR:}

1. Champagne FA, Curley JP. Epigenetic mechanisms mediating the long-term effects of maternal care on development. Neurosci Biobehav Rev 2009; 33: 593 - 6oo. [PubMed][CrossRef] 
2. Yehuda R, Daskalakis NP, Bierer LM et al. Holocaust Exposure Induced Intergenerational Effects on FKBP5 Methylation. Biol Psychiatry 2016; 80:372 - 8o. [PubMed][CrossRef]

3. Deary IJ, Penke L, Johnson W. The neuroscience of human intelligence differences. Nat Rev Neurosci 2010; 11: 201 - 11. [PubMed][CrossRef]

4. Foss R. Ingen gener for psykiske lidelser. Tidsskr Nor Psykol foren 2009; 46: 596 - 600.

5. Lien L, Huus G, Morken G. Psykisk syke lever kortere. Tidsskr Nor Legeforen 2015; 135: 246 - 8.

[PubMed][CrossRef]

Publisert: 5. mars 2018. Tidsskr Nor Legeforen. DOI: 10.4045/tidsskr.18.0148

(C) Tidsskrift for Den norske legeforening 2020. Lastet ned fra tidsskriftet.no 